\title{
Erratum to: Development of Risk-Realiability Based Underwater Inspection for Fixed Offshore Platforms in Indonesia
}

\author{
Ricky L. Tawekal ${ }^{1}$, Faisal D. Purnawarman ${ }^{1}$, Yati Mulyati ${ }^{2}$ \\ ${ }^{1}$ Bandung Institute of Technology, Ocean Engineering, Jl. Ganesha 10, Bandung, Indonesia \\ ${ }^{2}$ InstitutTeknologi Nasional, Civil Engineering, Jl. P.H.H. Mustafa 23, Bandung, Indonesia
}

Original article: MATEC Web of Conferences 147, 05002 (2018), https://doi.org/10.1051/matecconf/201814705002

The title of the article should be replaced by the following text:

Development of Risk-Reliability Based Underwater Inspection for Fixed Offshore Platforms in Indonesia 